\title{
INTERACTION OF FISCAL AND MONETARY POLICY IN THE CZECH REPUBLIC AND SLOVAKIA
}

\author{
[Interakce fiskální a monetární politiky v České republice a na Slovensku]
Jan Janků ${ }^{1}$, Stanislav Kappel ${ }^{2}$
${ }^{1}$ Vysoká škola báňská - Technická univerzita Ostrava, Ekonomická fakulta, Sokolská 33, 70121 Ostrava Email:jan.janku@vsb.cz \\ ${ }^{2}$ Vysoká škola báňská - Technická univerzita Ostrava, Ekonomická fakulta, Sokolská 33, 70121 Ostrava \\ Email:stanislav.kappel@vsb.cz
}

\begin{abstract}
The aim of this paper is to evaluate mutual interaction of fiscal and monetary policy in the Czech Republic and in Slovakia. The relationship - cooperation or conflict, are basic determinants of successful implementation for economic policy of the state. Fiscal and monetary policies have usually different aims and some conflict situations may arise. The game-theoretical approach is responsible for creating the theoretical model, which is then dealt with the empirical analysis by the method of the ordinary least squares. We find a stabilizing role of monetary policy in both countries and the dominant role of monetary policy in the Czech Republic.
\end{abstract}

Keywords: Fiscal Policy, Interactions, Monetary Policy, Policy Coordination, Policy Objectives.

JEL classification: E52, E58, E61, E62, E63

Doručeno redakci: 3.12.2013; Recenzováno: 3.5.2014; 19.5.2014; Schváleno k publikování: 23.9.2014

\section{Úvod}

Monetární politika patří spolu s fiskální politikou mezi základní hospodářské politiky státu. Rozhodování obou politik je na sobě nezávislé (centrální banka má svoji nezávislost př́mo definovanou v zákoně), obě politiky však při svém rozhodování musí brát v úvahu makroekonomické prostředí (veličiny, proměnné) a taktéž chování druhé z obou politik. Vzájemná spolupráce či souhra může mít pozitivní dopad na ekonomický vývoj země. Naopak konflikt obou politik může vést až ke ztrátě produkce a nakonec i k negativnímu dopadu na ekonomický růst.

Cíle obou politik (obou hospodářsko-politických autorit) jsou odlišné. Monetární politika, reprezentovaná centrální bankou, má jako svůj hlavní cíl péči o cenovou stabilitu (jako doplňkový cíl může mít podporu ekonomického růstu). Fiskální politika má za svůj hlavní cíl především podporu ekonomického růstu a dosažení nízké míry nezaměstnanosti, popř. vysoké míry zaměstnanosti. Za určité situace tak mohou být cíle obou politik v konfliktu. Obě politiky rovněž nemohou činit svá rozhodnutí bez ohledu na další makroekonomické veličiny. Tyto okolnosti vedou k poměrně složitému hospodářsko-politickému rozhodování.

Cílem příspěvku je posoudit vzájemné působení fiskální a monetární politiky v České republice a na Slovensku. Dalším cílem je zjistit, které proměnné ovlivňují rozhodování obou politik a zejména, zda obě politiky na sebe při svém rozhodování berou ohled.

Pro splnění těchto cílů je využita regresní analýza, prostř̌ednictvím níž je zkoumána statistická závislost hlavních nástrojů obou politik (pro fiskální politiku je to změna salda státního rozpočtu jako podílu na HDP, pro politiku monetární je to změna úrokové míry centrální banky) a zvolených nezávislých proměnných. Z reakčních funkcí jsou vyvozeny závěry, 
tj., které proměnné hrají důležitou roli při rozhodování obou politik a zda na sebe při svém rozhodování berou ohled. Dále jsou porovnávány obě země - Česká republika a Slovensko jejich společné a odlišné znaky. Obě země si jsou v mnohém podobné, obě země prošly podobným historicko-společenským vývojem, avšak Slovensko se stalo od roku 2009 jednou ze zemí eurozóny a přišlo tak de facto o svoji nezávislou měnovou politiku. K empirické analýze je využita regresní analýza a zkoumaným obdobím jsou čtvrtletní data od 1. čtvrtletí 2000 do 1. čtvrtletí roku 2013.

\section{Východiska empirické analýzy}

První studie vzájemného působení monetární a fiskální politiky lze spatřovat po druhé světové válce, např́klad v pracích Friedmana (1948) či Tinbergena (1954). Skutečný rozvoj analýzy (nepř́mého) vzájemného působení monetární a fiskální politiky však začíná v 80. letech 20. století publikací slavného článku Sargenta a Wallace (1981). Ti v reakci na Friedmana (1968) dokazují, že i když jsou v ekonomice splněny monetaristické předpoklady, může monetární autorita za jistých okolností ztrácet kontrolu nad cenovým vývojem. V tzv. slabé verzi fiskální teorie cenové hladiny ukazují, že Friedmanovo zlaté peněžní pravidlo nemusí vždy platit. Pokud se monetární autorita stane submisivním hráčem a fiskální autorita volí strategii deficitních rozpočtů, musí se monetární autorita z důvodu mezičasového rozpočtového omezení přizpůsobit. Fiskální autorita tedy může za určitých okolností znemožnit monetární autoritě kontrolovat cenový vývoj.

Dalšími autory, kteří zkoumají vzájemné působení fiskální a monetární politiky, jsou např́iklad Řežábek (2011), Leeper (2010), Balboni, Buti a Larch (2007), Onorante (2006), Dixit a Lambetini (2003), van Aarle, Engwerda a Plasmans (2002), Muscatelli, Tirelli a Trecroci (2002), Buti Roeger a Velt (2001), Melitz (2000) či Wyplosz (1999).

Buti, Roeger a Velt (2001) tvrdí, že konflikty mezi měnovou a fiskální politikou vznikají, pokud se účelové funkce centrální banky a vlády liší, což je obecně předpokládáno. Centrální banka má zpravidla jako hlavní cíl péči o cenovou stabilitu a vláda je zainteresována zejména na stabilizaci výstupu. Podobný názor zastávají např́íklad i Demertzis, Hughes Hallet a Viegi (2004).

Balboni, Buti a Larch (2007) zkoumají vzájemné působení fiskální a monetární politiky v Hospodářské a měnové unii (EMU) za předpokladu rozdílného názoru obou autorit na výši mezery výstupu. Přri rozdílném názoru na pozici ekonomiky v rámci hospodářského cyklu může docházet ke konfliktu. Náklady na tento konflikt mohou být sníženy, pokud se obě politiky dohodnou, nebo $\mathrm{v}$ př́padě herně-teoretické situace Stackelbergova typu interakce, kdy je jedna z politik lídr (vůdce). Vůdce v této situaci předpokládá reakci následovníka, nastavuje svoji politiku jako první a následovník je poté „nucen“ svou politiku nastavit v souladu s nastavením politiky vůdce. Wyplosz (1999) zkoumal země EU. Jako nástroj vlády, jakožto reprezentanta fiskální politiky, zvolil primární deficit a u monetární politiky jako nástroj centrální banky zvolil krátkodobou úrokovou míru. Rovnice odhaduje individuálně, separátně. Zkoumaným obdobím je období od roku 1980 do roku 1997. Dochází k závěru, že monetární politika reaguje vedle inflace také na výstup a to proticyklicky. Na zvyšující se inflaci reaguje monetární politika zvyšováním úrokové míry a na snižující se mezeru výstupu reaguje snižováním úrokové míry. Zároveň ale dodává, že právě odhad výstupu hraje velkou roli při výpočtu predikce inflace. Fiskální politika reaguje podobně, taktéž stabilizujícím zpo̊sobem, na výstup a do jisté míry i na inflaci. V závěru Wyplosz (1999) zmiňuje, že monetární a fiskální politika jsou do jisté míry zastupitelné jedna za druhou. Melitz (2000) zkoumal země OECD na ročních datech od roku 1959 do roku 1995. 
Odhady regresních rovnic pro fiskální a monetární politiku prováděl simultánně. Jako nástroj fiskální politiky zvolil primární saldo rozpočtu jako podíl $\mathrm{k}$ hrubému domácímu produktu, u monetární politiky zvolil jako nástroj sazbu na peněžních trzích. Došel k závěru, že fiskální politika plní (do jisté míry) stabilizační roli, daňové př́ijmy působí stabilizačně, vládní výdaje však destabilizačně. Fiskální politika a monetární politika jsou dle něj v konfliktu (uvolněná fiskální politika znamená př́ísnější monetární politiku).

Z českých autorů se interakcí monetární a fiskální politiky zabývá například Řežábek (2011) nebo Tomšík (2012). Řežábek (2011) zkoumá vzájemné působení monetární a fiskální politiky v České republice s různým odhadem potenciálního produktu, resp. mezery výstupu a to simultánně. Nástrojem monetární politiky je změna úrokové míry (dvoutýdenní repo sazby), nástrojem fiskální politiky je změna salda státního rozpočtu jako podílu k HDP (v základním modelu). $\mathrm{V}$ dalších, rozšířených modelech je to dále změna prŕíjmů státního rozpočtu jako podílu k HDP a změna výdajů státního rozpočtu jako podílu k HDP. Interakci obou politik řeší simultánně prostřednictvím Nashovy rovnováhy a dále pak pomocí sekvenčního rozhodování - Stackelbergovy rovnováhy, to vše za předpokladu nekooperativní hry. Z jeho závěrů plyne, že fiskální politika reaguje na monetární politiku ve stejném cyklickém směru. Dalším závěrem jeho studie je proticyklické chování obou politik, stabilizační reakce monetární politiky na inflaci a očekávanou inflaci. V České republice plní dle Řežábka (2011) roli vůdce monetární politika a fiskální politika roli následovníka. Dále dle něj existuje destabilizační účinek vládního dluhu na státní rozpočet. Posledním závěrem je, že obě politiky spolu nespolupracují při svém rozhodování (což i potvrzuje z jeho hospodářsko-politické praxe). Tomšík (2012) analyzuje interakci fiskální a monetární politiky z pohledu ČNB od roku 2004 do roku 2009. Dle něj dlouhodobé úrokové sazby - výnosů ze státních dluhopisů jsou jedním z důležitých determinantů tržních úrokových sazeb v dlouhém období. Dalším závěrem je procyklická fiskální politika (zejména v období vysokého ekonomického růstu). Nakonec autor popisuje, jak se chování fiskální politiky (fiskálními impulsy ovlivňujícími spotřebu, investice a směnný kurz) projevuje do predikcí ČNB.

\section{Specifikace modelu}

V rámci strategických perspektiv interakcí lze rozlišit antagonistický a neantagonistický konflikt, přičemž při analýze interakce fiskální a monetární politiky lze poměrně s jistotou předpokládat (i s ohledem na výše zmíněnou literaturu), že tato interakce (konflikt) bude neantagonistická, nebot' zájmy fiskální a monetární politiky nemusí být vždy v protikladu. Neantagonistický konflikt lze rozčlenit na kooperativní hru a nekooperativní hru. Domníváme se, že pro potřeby této práce je vhodnější nekooperativní hra a ztrátové funkce monetární a fiskální politiky tak musejí být odlišné a samostatné.

Řežábek (2011) uvádí, že v České republice (ale tvrzení může platit i pro Slovensko) lze $\mathrm{v}$ rámci teorie her uvažovat o nekooperativní rovnováze. V praxi to tedy znamená předpokládat, že centrální banka a fiskální autorita spolu v čase svého rozhodování o nastavení svého hospodářsko-politického nástroje nespolupracují. Zdůrazňuje, že toto je v souladu s jeho zkušenostmi s hospodářskou politikou v ČR i s platnou legislativou, která zajišt'uje nezávislost centrální banky na vládě. Navíc, jak již také bylo uvedeno výše, Buti, Roeger, Veld (2001) ve své práci uvádí, že v dostupné literatuře se všeobecně předpokládá stav, kdy se účelová funkce centrální banky liší od účelové funkce vlády (centrální banka je zaměřena na stabilizaci inflace pomocí úrokových sazeb, zatímco fiskální autorita je zaměřena na stabilizaci rozpočtu pomocí fiskálního deficitu). Řešení herně-teoretické kooperativní rovnováhy by znamenalo společnou (ztrátovou, účelovou) funkci centrální banky a fiskální autority (a obě hospodářsko-politické autority by tedy byly zaměřeny jak na stabilizaci inflace, tak na stabilizaci výstupu). 
Výchozími pracemi pro tvorbu reakčních funkcí empirické analýzy jsou zejména výše zmíněné studie Wyplosze (1999), Melitze (2000) a Řežábka (2011).

Model pro fiskální politiku:

$$
\Delta\left(\frac{s}{Y}\right)_{t}=\alpha_{0}+\alpha_{1} \Delta d_{t-1}+\alpha_{2} E y_{t}+\alpha_{3}\left(\frac{s}{Y}\right)_{t-1}+\alpha_{4} u_{t}+\alpha_{5} \Delta i_{t}+\varepsilon_{t},
$$

kde $\Delta\left(\frac{S}{Y}\right)_{t}$ je změna salda státního rozpočtu jako podílu k HDP mezi obdobím $t$ a obdobím $t-1$. Tato proměnná reprezentuje fiskální politiku. $\Delta d_{t-1}$ je o jedno období zpožděná změna vládního dluhu v absolutních hodnotách mezi obdobím $t$ a obdobím $t-1, E y_{t}$ predstavuje mezeru výstupu v čase $t,\left(\frac{s}{Y}\right)_{t-1}$ je zpožděná hodnota salda státního rozpočtu jako podílu vůči HDP o jedno období, $u_{t}$ je míra nezaměstnanosti $\mathrm{v} \% \mathrm{v}$ čase $t$ a $\Delta i_{t}$ je změna úrokové míry centrální banky mezi období $t$ a obdobím $t-1$. Tato proměnná reprezentuje monetární politiku.

Reakční funkce pro tvorbu modelu fiskální politiky vychází z předpokladu, že hlavním nástrojem fiskální politiky je změna salda státní rozpočtu jako podílu k HDP. Fiskální politika však při svém rozhodování musí brát na zřetel i další makroekonomické indikátory. V př́spěvku se předpokládá, že fiskální politika je ovlivňována vládním dluhem v absolutním vyjádření (resp. jeho změnami), mezerou výstupu (tzn., zda je ekonomika nad svým nebo pod svým potenciálním produktem), minulými saldy státního rozpočtu jako podílu na HDP, mírou nezaměstnanosti a změnou úrokové sazby centrální banky. Poslední proměnná reprezentuje monetární politiku a je na ni upřena zvýšená pozornost, nebot' může napovědět o formě vzájemných interakcí mezi fiskální a monetární politikou.

Model pro monetární politiku má poté následující podobu:

$$
\Delta i_{t}=\beta_{0}+\beta_{1} \Delta i_{t}^{G B}+\beta_{2} E y_{t}+\beta_{3} \Delta \pi_{t}+\beta_{4} \Delta\left(\frac{s}{Y}\right)_{t}+\epsilon_{t},
$$

kde $\Delta i_{t}$ reprezentuje nástroj monetární politiky a představuje změnu úrokové míry centrální banky mezi obdobím $t$ a obdobím $t-1 . \Delta i_{t}^{G B}$ je změna úrokové sazby desetiletého vládního dluhopisu mezi obdobím $t$ a obdobím $t-1, E y_{t}$ je mezera výstupu v čase $t, \Delta \pi_{t}$ je změna míry inflace zjištěná pomocí CPI mezi obdobím $t$ a obdobím $t-1$ a $\Delta\left(\frac{s}{Y}\right)_{t}$ je změna salda státního rozpočtu jako podílu $\mathrm{k}$ HDP mezi obdobím $t$ a obdobím $t-1$. Tato proměnná reprezentuje fiskální politiku.

Hlavním nástrojem monetární politiky je úroková sazba centrální banky, resp. její změna. $\mathrm{V}$ modelu je vycházeno $\mathrm{z}$ předpokladu, že monetární politika by při svém rozhodování měla brát v úvahu změnu výnosu desetiletého vládního dluhopisu. Tato proměnná aproximuje dlouhodobou úrokovou míru. Dále pak mezeru výstupu, změnu míry inflace a změnu salda státního rozpočtu jako podílu k HDP. Poslední proměnná reprezentuje fiskální politiku a je tedy v jistém ohledu klíčová (podobně jako nástroj monetární politiky v reakční funkci fiskální politiky).

U odhadnutých rovnic je v modelu sledována statistická významnost koeficientů a také jejich vazba. Předpokládané vazby koeficientů jsou uvedeny v Tabulce 1. 
Tabulka 1: Přepokládaná vazba nezávislých proměnných u fiskální a monetární politiky

\begin{tabular}{|c|c|c|c|}
\hline \multicolumn{2}{|c|}{ Fiskální politika $\Delta\left(\frac{S}{Y}\right)_{t}$} & \multicolumn{2}{|c|}{ Monetární politika $\Delta i_{t}$} \\
\hline Proměnná & Předpokládaná vazba & Proměnná & Předpokládaná vazba \\
\hline$\Delta d_{t-1}$ & + & $\Delta i_{t}^{G B}$ & + \\
\hline$E y_{t}$ & + & $E y_{t}$ & + \\
\hline$\left(\frac{S}{Y}\right)_{t-1}$ & - & $\Delta \pi_{t}$ & + \\
\hline$u_{t}$ & - & $\Delta\left(\frac{S}{Y}\right)_{t}$ & $\begin{array}{c}+ \text { (souhra) / } \\
-(\text { střet })\end{array}$ \\
\hline$\Delta i_{t}$ & $\begin{array}{c}+ \text { (souhra) / } \\
\text { - (střet) }\end{array}$ & & \\
\hline
\end{tabular}

Zdroj: vlastní zpracování

Nejprve jsou uvedeny předpokládané vazby pro fiskální politiku. V př́padě rostoucího vládního dluhu $\Delta d_{t-1}$ by měla fiskální politika reagovat snižováním deficitů, potažmo dosahováním přebytků, aby snižovala vládní dluh. Proto je očekávaná kladná vazba. V př́padě kladné mezery výstupu $E y_{t}$ by měla fiskální politika provádět restrikci (a naopak v př́padě záporné mezery výstupu provádět fiskální expanzi), proto je uvedena kladná vazba. $\mathrm{U}$ proměnné zpožděná hodnota salda státního rozpočtu jako podílu $\mathrm{k} H D P$ $\left(\frac{S}{Y}\right)_{t-1}$ je očekávaná záporná vazba, která implikuje, že nástroj fiskální politiky nepůsobil zcela, ale pouze částečně a přizpůsobení nastává $\mathrm{i} v$ dalším období. U míry nezaměstnanosti $u_{t}$ je předpokládaná záporná vazba. Při rostoucí nezaměstnanosti by měla vláda provádět expanzi, aby stimulovala agregátní poptávku a tím i zprostředkovaně snižovala nezaměstnanost. U poslední proměnné, reprezentující monetární politiku $\Delta i_{t}$, mohou nastat dvě situace. $\mathrm{V}$ př́padě kladné vazby existuje mezi oběma politikami souhra - obě provádějí expanzi nebo restrikci. V případě záporné vazby jsou obě politiky ve střetu, jedna provádí expanzi a druhá restrikci.

V reakční funkci monetární politiky je u proměnné $\Delta i_{t}^{G B}$ očekávaná kladná vazba. Při rostoucím výnosu z dluhopisů ekonomické subjekty očekávají vyšší inflaci, na což by monetární politika měla reagovat monetární restrikcí, tj. zvyšovat úrokové sazby. U mezery výstupu $E y_{t}$ je situace analogická jako v případě fiskální politiky, proto je očekávaná kladná vazba. Při rostoucí inflaci $\Delta \pi_{t}$ musí monetární politika provádět restrikci - zvyšovat úrokové sazby, proto je opět očekávaná kladná vazba. U poslední proměnné, reprezentují fiskální politiku $\Delta\left(\frac{S}{Y}\right)_{t}$, mohou opět nastat dvě situace. V př́padě kladné vazby dochází k souhře obou politik a v př́padě záporné vazby $\mathrm{k}$ střetu obou politik.

Rovnice jsou odhadnuty metodou nejmenších čtverců (MNČ), je provedena statistická, ekonomická a ekonometrická verifikace (tj. provedeny základní ekonometrické testy). Jsou zjišt’ovány statistické významnosti jednotlivých proměnných a vazby u odhadnutých parametrů. Díky výše uvedenému je zjištěno, zda monetární a fiskální politika na sebe reagují a které proměnné jsou při jejich rozhodování relevantní. Data jsou čerpána $\mathrm{z}$ databáze Evropské centrální banky (deficit státního rozpočtu jako podílu k HDP), evropského statistického úřadu Eurostat (proměnná mezera výstupu, která je odhadnutí pomocí Hodrickova-Prescotova filtru $\mathrm{z}$ meziročních temp růstu HDP; proměnná úroková sazba centrální banky'; míra nezaměstnanosti, resp. čtvrtletní průměry měsíční míry

\footnotetext{
${ }^{1}$ Úrokovou sazbou centrální banky je myšlena hlavní měnově-politická sazba monetární autority využívaná při operacích na volném trhu. Tyto sazby jsou označovány jako Official Refinancing Operation Rates. Např́klad v př́padě České republiky je to dvoutýdenní repo sazba. U Slovenska je to po vstupu do eurozóny (tj. po roce 2009) hlavní úroková sazba ECB.
} 
nezaměstnanosti; vládní dluh v absolutním vyjádření v měnových jednotkách dané země; míra výnosu desetiletého vládního dluhopisu²) a OECD (míra inflace měřená pomocí indexu spotřebitelských cen CPI). Sledovaným obdobím jsou čtvrtletní pozorování od 1. čtvrtletí roku 2000 do 1. čtvrtletí roku 2013. Zkoumanými zeměmi jsou Česká republika a Slovensko.

\section{Výsledky empirické analýzy}

V Tabulkách 2 a 3 jsou uvedeny výsledky modelů. V Tabulce 2 jsou uvedeny výsledky pro Českou republiku, v Tabulce 3 pak výsledky pro Slovensko.

Tabulka 2: Reakce fiskální a monetární politiky v České republice

\begin{tabular}{|c|c|c|c|c|c|}
\hline \multicolumn{3}{|c|}{ Závislá proměnná $\Delta\left(\frac{S}{Y}\right)_{t}$} & \multicolumn{3}{|c|}{ Závislá proměnná } \\
\hline $\begin{array}{l}\text { Nezávislá } \\
\text { proměnná }\end{array}$ & Koeficient & \multirow{6}{*}{$\begin{array}{c}\text { Adjusted R- } \\
\text { square } \\
0,62 \\
\text { F-statistika } \\
19,98^{*} * * \\
\text { Počet } \\
\text { pozorování } \\
51\end{array}$} & $\begin{array}{l}\text { Nezávislá } \\
\text { proměnná }\end{array}$ & Koeficient & \multirow{5}{*}{$\begin{array}{c}\text { Adjusted R-square } \\
0,50 \\
\text { F-statistika } \\
12,86^{* * *} \\
\text { Počet pozorování } \\
48\end{array}$} \\
\hline$\Delta d_{t-1}$ & $\begin{array}{c}-8,39 \mathrm{E}-07 \\
(-0,08)\end{array}$ & & $\Delta i_{t}^{G B}$ & $\begin{array}{c}0,17 * \\
(1,9)\end{array}$ & \\
\hline $\boldsymbol{E} \boldsymbol{y}_{t}$ & $\begin{array}{c}0,18 \\
(0,99)\end{array}$ & & $\boldsymbol{E} \boldsymbol{y}_{t}$ & $\begin{array}{c}0,03 * * \\
(2,02)\end{array}$ & \\
\hline$\left(\frac{S}{Y}\right)_{t-1}$ & $\begin{array}{c}-1,11 * * * \\
(-8,67)\end{array}$ & & $\Delta \pi_{t}$ & $\begin{array}{c}0,16 * * * \\
(4,27)\end{array}$ & \\
\hline$u_{t}$ & $\begin{array}{c}-0,96 * * * \\
(-2,98) \\
\end{array}$ & & $\Delta\left(\frac{S}{Y}\right)_{t}$ & $\begin{array}{c}0,01 \\
(1,32) \\
\end{array}$ & \\
\hline$\Delta \boldsymbol{i}_{t}$ & $\begin{array}{c}5,08 * * * \\
(4,01)\end{array}$ & & & & \\
\hline
\end{tabular}

Zdroj: vlastní výpočty

Pozn.: V závorkách jsou uvedeny hodnoty t-statistiky; *, **, *** označuje hladinu významnosti 10\%, 5\%, 1\%.

V reakční funkci fiskální politiky v České republice jsou statisticky významnými proměnnými zpožděná hodnota salda státního rozpočtu jako podílu k HDP $\left(\frac{s}{Y}\right)_{t-1}$, míra nezaměstnanosti $u_{t}$ a změna úrokové sazby $\Delta i_{t}$. U proměnné $\left(\frac{s}{Y}\right)_{t-1}$ je záporná vazba, která naznačuje setrvačnost přizpůsobení fiskální politiky na minulém období. U proměnné míra nezaměstnanosti $u_{t}$ je taktéž záporná vazba, která je v souladu s očekáváním. Fiskální politika reaguje na zvýšení nezaměstnanosti expanzivní fiskální politikou. U proměnné $\Delta i_{t}$ reprezentující monetární politiku je kladná vazba. Fiskální politika reaguje na monetární politiku ve stejném cyklickém směru. Zbylé proměnné jsou statisticky nevýznamné. Vazba proměnné mezery výstupu $E y_{t}$ je v souladu s očekáváním, což by značilo proticyklickou fiskální politiku. Naopak vazba u proměnné $\Delta d_{t-1}$ je v rozporu s očekáváním. Fiskální politika tedy nereaguje na předchozí kumulaci vládního dluhu.

U monetární politiky jsou všechny proměnné statisticky významné, s výjimkou proměnné reprezentující fiskální politiku, což značí, že monetární politika při svém rozhodování nebere ohled na politiku fiskální. U ostatních proměnných jsou vazby v souladu s očekáváním. Na očekávanou vyšší inflaci, na kladnou mezeru výstupu i na rostoucí inflaci reaguje centrální banka monetární restrikcí - zvyšuje úrokové sazby a vice versa. V Tabulce 3 jsou uvedeny výsledky pro Slovensko.

\footnotetext{
${ }^{2}$ Jedná se o čtvrtletní průměry.
} 
Tabulka 3: Reakce fiskální a monetární politiky na Slovensku

\begin{tabular}{|c|c|c|c|c|c|}
\hline \multicolumn{3}{|c|}{ Závislá proměnná $\Delta\left(\frac{s}{Y}\right)_{t}$} & \multicolumn{3}{|c|}{ Závislá proměnná } \\
\hline $\begin{array}{l}\text { Nezávislá } \\
\text { proměnná }\end{array}$ & Koeficient & \multirow{6}{*}{$\begin{array}{c}\text { Adjusted R- } \\
\text { square } \\
0,39 \\
\text { F-statistika } \\
7,51 * * * \\
\text { Počet } \\
\text { pozorování } \\
51\end{array}$} & $\begin{array}{l}\text { Nezávislá } \\
\text { proměnná }\end{array}$ & Koeficient & \multirow{5}{*}{$\begin{array}{c}\text { Adjusted R-square } \\
0,22 \\
\text { F-statistika } \\
4,41 * * * \\
\text { Počet pozorování } \\
48\end{array}$} \\
\hline$\Delta \mathbf{d}_{\mathrm{t}-1}$ & $\begin{array}{l}0,001 \\
(1,55)\end{array}$ & & $\Delta i_{t}^{G B}$ & $\begin{array}{l}0,008 \\
(0,05)\end{array}$ & \\
\hline $\boldsymbol{E} \boldsymbol{y}_{t}$ & $\begin{array}{c}0,44 * * * \\
(3,33)\end{array}$ & & $E y_{t}$ & $\begin{array}{c}0,09 * * * \\
(3,92)\end{array}$ & \\
\hline$\left(\frac{S}{Y}\right)_{t-1}$ & $\begin{array}{c}-0,47 * * * \\
(-4,24)\end{array}$ & & $\Delta \pi_{t}$ & $\begin{array}{c}-0,04 \\
(-0,64)\end{array}$ & \\
\hline$u_{t}$ & $\begin{array}{c}-0,06 \\
(-0,52) \\
\end{array}$ & & $\Delta\left(\frac{S}{Y}\right)_{t}$ & $\begin{array}{c}-0,04 * * \\
(-2,1)\end{array}$ & \\
\hline$\Delta i_{t}$ & $\begin{array}{l}-2,07 * * \\
(-2,54)\end{array}$ & & & & \\
\hline
\end{tabular}

Zdroj: vlastní výpočty

Pozn.: V závorkách jsou uvedeny hodnoty t-statistiky; *, **, *** označuje hladinu významnosti 10\%, 5\%, 1\%.

Ve výsledném modelu jsou pro fiskální politiku na Slovensku statisticky významné proměnné mezera výstupu $E y_{t}$, zpožděná hodnota salda státního rozpočtu jako podílu k HDP $\left(\frac{s}{Y}\right)_{t-1}$ a proměnná reprezentující monetární politiku $\Delta i_{t}$. U proměnné mezera výstupu je výsledná vazba v souladu s očekáváním. Fiskální politika na Slovensku působí proticyklicky. Proměnná míra nezaměstnanosti také naznačuje proticyklickou fiskální politiku (na vyšší nezaměstnanosti reaguje fiskální politika expanzí - záporná vazba), nicméně tato proměnná není statisticky signifikantní. Záporná vazba $\left(\frac{s}{Y}\right)_{t-1}$ naznačuje setrvačnost přizpůsobení fiskální politiky na minulém období. Poslední statisticky významnou proměnnou je reprezentant monetární politiky $\Delta i_{t}$. Záporná vazba značí střet obou politik. Proměnná $\Delta d_{t-1}$ má kladnou vazbu, což by značilo, se fiskální politika reaguje na rostoucí vládní dluh stabilizačně - snižuje deficity. Tato proměnná je však statisticky nevýznamná.

V př́padě monetární politiky na Slovensku jsou statisticky významnými proměnné mezera výstupu $E y_{t}$ a proměnná reprezentující fiskální politiku $\left(\frac{S}{Y}\right)_{t-1}$. U proměnné mezera výstupu je vazba v souladu s očekáváním, což naznačuje proticykličnost a stabilizační roli monetární politiky. U proměnné $\left(\frac{s}{Y}\right)_{t-1}$ je záporná vazba. Monetární politika při svém rozhodování bere v potaz reakci fiskální politiky a reaguje v opačném směru (dochází ke střetu). Proměnná $\Delta i_{t}^{G B}$ má očekávanou vazbu. Na zvyšující se očekávanou inflaci reaguje monetární politika restrikcí. Proměnná však není statisticky signifikantní. Statisticky insignifikantní je taktéž proměnná změna míry inflace $\Delta \pi_{t}$. Její vazba je navíc v rozporu s očekáváním.

\section{Diskuse výsledků}

V Tabulce 4 jsou shrnuty vazby koeficientů regresních parametrů výsledných modelů včetně původně očekávaných vazeb. 
Tabulka 4: Výsledné vazby koeficientů

\begin{tabular}{|c|c|c|c|c|c|c|c|}
\hline $\begin{array}{c}\text { Fiskální } \\
\text { politika } \\
\boldsymbol{\Delta}\left(\frac{\boldsymbol{s}}{\boldsymbol{Y}}\right)_{\boldsymbol{t}}\end{array}$ & $\mathbf{C Z}$ & $\mathbf{S K}$ & $\begin{array}{c}\text { očekávaná } \\
\text { vazba }\end{array}$ & $\begin{array}{c}\text { Monetární } \\
\text { politika } \\
\Delta \boldsymbol{i}_{\boldsymbol{t}}\end{array}$ & $\mathbf{C Z}$ & SK & $\begin{array}{c}\text { očekávaná } \\
\text { vazba }\end{array}$ \\
\hline$\Delta \mathbf{d}_{\mathrm{t}-1}$ & - & + & + & $\Delta \boldsymbol{i}_{t}^{G B}$ & $+*$ & + & + \\
\hline $\boldsymbol{E} \boldsymbol{y}_{\boldsymbol{t}}$ & + & $+* * *$ & + & $\boldsymbol{E} \boldsymbol{y}_{\boldsymbol{t}}$ & $+* *$ & $+* * *$ & + \\
\hline$\left(\frac{\boldsymbol{S}}{\boldsymbol{Y}}\right)_{\boldsymbol{t}-\mathbf{1}}$ & $-* * *$ & $-* * *$ & - & $\Delta \boldsymbol{\pi}_{\mathbf{t}}$ & $+*$ & - & + \\
\hline $\boldsymbol{u}_{\boldsymbol{t}}$ & $-* * *$ & - & - & $\Delta\left(\frac{\boldsymbol{S}}{\boldsymbol{Y}}\right)_{\boldsymbol{t}}$ & + & $-* *$ & $+/-$ \\
\hline$\Delta \boldsymbol{i}_{\boldsymbol{t}}$ & $+* * *$ & $-* *$ & $+/-$ & & & & \\
\hline
\end{tabular}

Zdroj: vlastní výpočty

Pozn.: *, **, *** označuje hladinu významnosti 10\%, 5\%, 1\%.

Ani u jedné z obou zkoumaných zemí nebyla zjištěna statisticky významná reakce fiskální politiky na změnu vládního dluhu $\mathrm{v}$ absolutní výši. Tato proměnná tedy nehraje roli při rozhodování vlády ani u jedné ze zkoumaných zemí. Proměnná mezera výstupu byla statisticky významná v př́ípadě Slovenska. Kladná vazba u obou zemí (u České republiky se statistická významnost neprokázala) ukazuje na proticyklickou fiskální politiku. Taktéž u proměnné $\left(\frac{S}{Y}\right)_{t-1}$ je vazba v souladu s očekáváním. U obou zemí je navíc tato proměnná statisticky významná. Nástroj fiskální politiky tedy nepůsobí zcela v daném období, ale přizpůsobení nastává částečně i v dalším období. Další proměnná, míra nezaměstnanosti, má zápornou vazbu, což je v souladu s očekáváním. Na rostoucí nezaměstnanost reaguje fiskální politika expanzí a vice versa. Statistická významnost byla však zjištěna pouze u České republiky. Poslední proměnná, reprezentující monetární politiku, byla u obou zemí statisticky významná. U České republiky je u této proměnné kladná vazba. Díky tomu, že v reakční funkci monetární politiky v České republice je nezávislá proměnná $\Delta\left(\frac{S}{Y}\right)_{t}$ statisticky nevýznamná a má kladnou vazbu, lze vyvodit několik závěrů. Monetární politika nebere v úvahu při svém rozhodování politiku fiskální. Fiskální politika naopak bere při svém rozhodování v potaz monetární politiku. Kladné vazby navíc naznačují souhru obou politik. Z toho tedy plyne, že monetární politika je v České republice v dominantní roli. Fiskální politika reaguje stejným směrem na kroky monetární politiky. V prŕípadě Slovenska je situace opačná a poněkud složitější. Obě politiky berou při svém rozhodování v potaz chování druhé z politik, ale záporné vazby naznačují střet obou politik (statisticky významná proměnná reprezentující monetární politiku v reakční funkci fiskální politiky a statisticky významná proměnná reprezentující fiskální politiku v reakční funkci monetární politiky). Z toho lze vyvodit závěr, že obě politiky se snaží navzájem si vnutit své představy o hospodářské politice.

Zbylé proměnné v reakční funkci monetární politiky jsou v př́ípadě České republiky statisticky významné a vazba je v souladu s očekáváním. Monetární politika v České republice plní výrazně stabilizační roli. Poněkud jiná je situace u reakční funkce monetární politiky na Slovensku. Statisticky významnou je proměnná mezera výstupu. Vazba u této proměnné je $\mathrm{v}$ souladu s očekáváním, což by značilo stabilizační roli monetární politiky v této zemi. Nicméně další proměnná $\Delta i_{t}^{G B}$ je už statisticky nevýznamná (vazba je v souladu s očekáváním) a poslední proměnná $\Delta \pi_{t}$ je taktéž statisticky nevýznamná (vazba navíc není v souladu s očekáváním). 


\section{Závěr}

Tato studie a zejména výše uvedená diskuse empirických výsledků přináší některé zajímavé výsledky v oblasti fiskálně-monetárních interakcích ve dvou ekonomicky, institucionálně i historicky podobných ekonomikách - v České republice a na Slovensku.

Cílem článku bylo posoudit vzájemné působení fiskální a monetární politiky v těchto zemích a zjistit, které proměnné ovlivňují rozhodování těchto politik. Předchozí, čtvrtá kapitola, která se věnovala sumarizaci a intepretaci dosažených empirických zjištění, naznačila především hlavní rozdíly mezi zkoumanými zeměmi. Je velmi pravděpodobné, že klíčovým rozdílem, jenž v konečném důsledku dává podobu fiskálně-monetárním interakcím v obou zemích, je rozdíl navýsost institucionální - autonomní či neautonomní monetární politika.

Slovenská republika svým vstupem do eurozóny v roce 2009 fakticky ztratila zcela autonomní monetární politiku. I v letech předešlých však byla monetární politika Slovenska omezena. Již v roce 2005 Slovensko vstoupilo do Evropského mechanismu směnných kurzů II (ERM II) a vedle cílování inflace tak bylo rozhodování o monetární politice podřízeno také udržování fixního kurzu měny (a tedy de facto plnění dvou monetárních cílů zároveň).

Monetární politika v České republice se ukázala býti v dominantní roli, nebot' fiskální politika se jí do jisté míry podřizuje. V případě Slovenska je situace opačná a poněkud složitější. Zdá se, jako by si obě politiky pokoušely navzájem vnutit své představy o hospodářské politice. Výše zmíněné by však pravděpodobně platilo pouze v případě, že by monetární politika v SR byla zcela autonomní a tedy realizována na národní úrovni. Vzhledem ke společné měnové politice zemí eurozóny lze však spíš výše uvedené interpretovat tak, že se slovenská fiskální politika pokouší korigovat či neutralizovat rozhodnutí nadnárodní monetární autority a i zpětně jsou její rozhodnutí v nesouladu s touto autoritou, nebot' ta rovněž realizuje opatření opačná, vyvažující.

Uvedenému ve skutečnosti odpovídají i dílčí výsledky reakčních funkcí monetární a fiskální politiky na Slovensku a v České republice. V České republice hraje významnou stabilizační roli monetární politika, přičemž fiskální politika v tomto ohledu mírně zaostává. Společná měnová politika zemí eurozóny však přirozeně nemá příliš stabilizační vliv na makroekonomické proměnné Slovenské republiky, jež tvoří přibližně $0,75 \%$ HDP zemí eurozóny. Proto není překvapením, že ve Slovenské republice nahrazuje stabilizační úlohu monetární politiky politika fiskální, která se v tomto ohledu zdá býti více stabilizujícím prvkem slovenské ekonomiky, než je stabilizujícím prvkem české ekonomiky fiskální politika realizovaná v ČR.

\section{Poděkování}

Tento článek vznikl za finanční podpory Studentské grantové soutěže Ekf, VŠB-TU Ostrava v rámci projektu SP2013/179 „Interakce monetární a fiskální politiky v kontextu teorie her v zemích Visegradské skupiny“.

\section{Literatura}

[1] BALBONI, F., M. BUTI and M. LARCH, 2007. ECB vs. Council vs. Commission: Monetary and Fiscal Policy Interactions in the EMU When Cyclical Conditions are Uncertain. European Economy. Economic Papers, May 2007. ISBN 978-92-79-046308. 
[2] BUTI, M., W. ROEGER and J. VELD in't, 2001. Monetary and Fiscal Policy Interactions under a Stability Pact. Economics Working Papers from European University Institute, No ECO2001/08.

[3] DEMERTZIS, M., A. HUGHES HALLET and N. VIEGI, 2004. An independent central bank faced with elected governments. European Journal of Political Economy, 20(4), 907-922. ISSN 0176-2680.

[4] DIXIT, A. and L. LAMBERTINI, 2003. Interactions of Commitment and Discretion in Monetary and Fiscal Policies. The American Economic Review, 93(5), 1522-1542. ISSN 0002-8282.

[5] FRIEDMAN, M., 1948. A Monetary and Fiscal Framework for Economic Stability. The American Economic Review, 38(3), 245-264. ISSN 0002-8282.

[6] FRIEDMAN, M., 1968. The Role of Monetary Policy. The American Economic Review, 58(1), 1-17. ISSN 0002-8282.

[7] LEEPER, E. M., 2010. Monetary Science, Fiscal Alchemy. NBER Working Paper No. 16510.

[8] MELITZ, J., 2000. Some Cross-Country Evidence about Fiscal Policy Behavior and Consequences for EMU. CREST-INSEE, and CEPR.

[9] MUSCATElli, A., P. TIRELLI and C. TRECROCI, 2002. Monetary and Fiscal Policy Interactions over the Cycle: Some Empirical Evidence. Business School Economics, University of Glasgow Working Papers, No 2002/13, October 2002.

[10] ONORANTE, L., 2006. Interaction of fiscal policies on the Euro area: how much pressure on the ECB? Economics Working Papers from European University Institute, No ECO 2006/9.

[11] ŘEŽÁBEK, P., 2011. Měnová politika a její interakce s politikou fiskální. Praha: Karolinum. ISBN 978-80-246-1894-4.

[12] SARGENT, T. J. and N. WALLACE, 1981. Some Unpleasant Monetarist Arithmetic. Federal Reserve Bank of Minneapolis Quarterly Review, 5(3), 1-17. ISSN 0271-5287.

[13] TINBERGEN, J., 1954. Centralization and Decentralization in Economic Policy. Amsterdam: North Holland Pub. Co.

[14] TOMŠÍK, V., 2012. Some Insights into Monetary and Fiscal Policy Interactions in the Czech Republic. BIS Papers: Fiscal Policy, Public Debt and Monetary Policy in Emerging Market Economies, 67, 161-171. ISSN 98-9197-152-9.

[15] VAN AARLE, B., J. ENGWERDA and J. PLASMANS, 2002. Monetary and Fiscal Policy Interaction in the EMU: A Dynamic Game Approach. Annals of Operations Research, 109(1-4), 229-264. ISSN 1572-9338.

[16] WYPLOSZ, Ch. 1999. Economic Policy Coordination in EMU: Strategies and Institutions. ZEI Policy Paper, B11. 